\title{
ADVERSE EVENTS AFTER PANDEMIC FLU A/H1N1 VACCINATION IN CHILDREN: CONCERN ABOUT VACCINE SAFETY
}

\author{
Birutė Strukčinskienė ${ }^{1}$, Sigitas Griškonis ${ }^{2,1}$ \\ ${ }^{1}$ Klaipeda University, Faculty of Health Sciences, Klaipeda, Lithuania, \\ ${ }^{2}$ Klaipeda University Hospital, Klaipeda, Lithuania
}

Key words: adverse events, children, pandemic flu, vaccination, vaccine safety.

\footnotetext{
Summary

Vaccination is essential tool for the management and control of infectious diseases. However, it can cause adverse events. After novel Pandemic ("swine") flu virus A H1N1 rapid spread in 2009 all over the world and mass vaccination initiatives, the sudden increase in childhood narcolepsy with cataplexy in some countries has occurred. It stunned medical and public health society, and general population, what increased awareness of recorded side effects and vaccine safety. An integrative review of the literature was conducted and extra search of reports and documents was performed.

Despite adverse events were recorded after vaccination against pandemic flu, side effects bear very small proportion of all vaccinated. Vaccination against swine flu can cause generalized, flu-like, neurological, gastrointestinal, and allergic-type symptoms. A more serious complication, which has been identified, is narcolepsy with cataplexy. The incidence of narcolepsy with cataplexy in children and adolescents in European countries increased during the pandemic and vaccination period. The use of adjuvants has been shown to provoke some adverse events.

Vaccination safety remains a priority issue in vaccination science. It is of high importance to devout finances, to form vaccine policy, to coordinate vaccine research, and to promote vaccine investigation, creation, and improvements. Safe vaccination will encourage population and empower societies for wider usage of vaccination as the mean for flu control, especially in children.
}

\section{Introduction}

Immunization is essential for the management and control of infectious diseases. Vaccination is an important measure of public health strategies for communicable diseases prevention. It is the main tool for protecting population against flu pandemics. Despite the tremendous efforts of scientific community and big army of researchers, vaccination still can cause adverse events.

After the novel flu virus A H1N1 (so called "swine flu") rapidly spread all over the world in 2009, mass vaccination started globally, which led to unexpected complications. The sudden increase in childhood narcolepsy with cataplexy in the Nordic countries enhanced the need to analyse vaccination safety [1-3]. In 2009-2010 in Sweden 81 cases of narcolepsy with cataplexy in children and adolescents after vaccination against pandemic flu A H1N1 were reported. This was followed by an increasing number of similar complications in Finland, Iceland, Norway, and Ireland [1-6]. It stunned medical and public health society, and general population. The awareness of recorded adverse events after pandemic flu vaccination in children and of vaccination safety was raised among researchers, healthcare, public health professionals, and society. This forces to study the adverse events after vaccination, and to improve vaccination safety.

The aim of the study: to analyze adverse events after Pandemic flu $\mathrm{A} / \mathrm{H} 1 \mathrm{~N} 1$ vaccination in children with concern about vaccine safety.

\section{Materials and methods}

An integrative review of the literature was conducted using the databases: MEDLINE, EBSCO Publishing, Wiley Online Library, Lippincott Williams \& Wilkins Custom, SAGE Journals Online, Science Direct, Oxford Journals Online, Directory of Open Access Journals (DOAJ), and Google Scholar Database. Extra manual search of referen- 
ces/reports/documents was performed. Findings reporting pandemic/swine-origin influenza/flu, A/H1N1, virus (SOIV), vaccination/immunization and complications/adverse effects/adverse events following immunization (AEFI)/ vaccine adverse events/side effects after vaccination/vaccine safety/immunization safety in children were included.

\section{Results}

1. The role of vaccination. Vaccination is the best way to prevent pandemics. Vaccination has helped to avoid serious complications and mortality from diseases like polio, diphtheria and Haemophilus influenzae infections. Immunization programs have led to reduced morbidity and mortality from fast spreading infectious diseases such as measles, pertussis, rubella and mumps. Vaccination remains of great importance for influenza prevention. Children infected with flu shed viruses in great quantities and for long duration. Therefore, vaccination of children has been shown to decrease the burden of disease in other children, the family, and community. Influenza vaccination is recommended for children aged more than 6 months, especially for those with neurological disorders, chronic pulmonary disease, asthma, and cardiac disease [7-10].

However, vaccine against flu coverage in children nowadays is insufficient. Because of the lack of information, low public awareness and insufficient knowledge, and intolerance to adverse reactions, flu vaccine coverage in children is low: $9-41 \%$. This is in contrast with routine childhood immunizations, where, for instance, $78 \%$ coverage rates have been achieved [11-13]. The main reasons to the low level of flu vaccination include fear, doubt of necessity, concerns about vaccine safety and side-effects (e. g., risk of Guillain-Barré syndrome), lack of belief in the effect of vaccination, the limited knowledge about adjuvanted vaccines, and doubts in the vaccine development process $[12,14-17]$. In France, the majority of the adult population expressed concerns about the pandemic vaccines' safety and refused vaccination for themselves and their children [16]. A study in Australia revealed that only $45 \%$ of participants believed that the H1N1 vaccine would protect them against acquiring "swine flu", and a similar proportion was concerned about the safety of the vaccine and the possibility of side effects. Common fears expressed, were that: the vaccine had been "rushed through", there had been "insufficient research", the vaccine had not been "tested adequately", and "long term studies" were required to ensure its "safety" [15].

Public health specialists, medical staff, especially pediatricians promote immunization programs and provide information for society on need of vaccination. Healthca- re professionals try to identify those at risk, carry through vaccination programs, and provide related health education [7]. They put efforts to encourage population to vaccinate themselves and their children. However, these efforts are still not enough.

2. Pandemic influenza A /H1N1. The new pandemic influenza A /H1N1 virus (S-OIV) emerged in April 2009. There after (in June 2009) the World Health Organization (WHO) announced the phase 6 of influenza pandemic. According to WHO, phase 6 indicates that the same identified virus has caused sustained outbreaks in two or more countries in one WHO region and in at least one other country in another WHO region $[12,18]$.

It was the first pandemic caused by the novel virus $\mathrm{S}$ OIV A /H1N1 in the 21st century, as influenza A (H1N1) subtype viruses have rarely predominated since the 1957 pandemic [19, 20]. Influenza A virus strains caused three major global epidemics during the 20th century: the Spanish flu in 1918 (20 to 100 million deaths), Asian flu in 1957 (2 million deaths) and Hong Kong flu in 1968-69 (1 million deaths). These pandemics were caused by strains of Influenza A virus that had undergone major genetic changes and for which the population did not possess significant immunity [21].

The 2009 pandemic started at the border between United States and Mexico and later caused significant morbidity and mortality worldwide [8, 19]. As of June 2009 WHO stated that 76 countries had reported more than 35, 000 cases of swine flu, including 163 deaths; 108 of those had occurred in Mexico [22]. The epidemic had spread to many countries around the world from Latin America to Europe, including the Nordic countries. As per August 2009 data, total laboratory confirmed cases worldwide were 1,82,166 and the number of deaths was 1799; 3987 cases and 100 deaths in India, 8975 cases and 15 deaths in the US, 1336 cases with 2 deaths in Canada, and by October, 2009, 6910 cases and 185 deaths in Australia [14, 21, 23]. In EU/EEA countries, in total, 51,768 confirmed cases of pandemic flu and 159 deaths were reported over April - September 2009 [24]. In 2010, 214 countries had reported A/ H1N1 cases, with more than 18,000 deaths worldwide. For instance, in Canada, 428 people died, while in Australia 37,713 confirmed cases were recorded, including 191 pandemic flu associated deaths $[12,15]$.

The most common cause of death in pandemic flu was respiratory failure, and other causes of death were pneumonia (leading to sepsis), high fever (leading to neurological problems), dehydration (from excessive vomiting and diarrhea) and electrolyte imbalance [21]. Reported deaths in children included pneumonia, acute respiratory distress 
syndrome, sepsis, shock, and encephalopathy/encephalitis [8]. The severe illness and mortality were related to secondary bacterial infections, and Staphylococcus aureus was the most common bacterial pathogen identified $[8,9]$. For swine flu treatment, antiviral drugs oseltamivir (Tamiflu) and zanamivir (Relenza) were recommended. They were effective if taken within 2 days of appearing of symptoms, and acted through deactivating the neuraminidase enzyme, which the virus needs to grow and spread [21].

The distribution of pandemic flu cases was similar across different geographic areas, and no statistically significant differences arose with regard to the race and ethnicity $[8,10]$. Pandemic flu mostly affected pre-school children, schoolchildren and young people $[9,10,15,20,24]$. In Europe, the majority ( $78 \%$ ) of the affected individuals was less than 30 years of age, and in Australia, the highest rate of hospitalization occurred among children less than 5 years of age. In the US, the median age at death from pandemic flu was 9.4 years, and the majority of them $(72 \%)$ were aged 5-17 years $[8,15,24]$.

The morbidity rates from $\mathrm{A} / \mathrm{H} 1 \mathrm{~N} 1$ virus infection were highest in children and young people, and it might be because the pandemic $\mathrm{A} / \mathrm{H} 1 \mathrm{~N} 1$ virus was a new strain to which young people have had no immunity $[12,21]$. Fatal cases occurred mostly in children and in the elderly $[9,10$, $20,21,23]$. Above the age of 60 , there was a steep decline in the number of pandemic flu cases [24]. This could be related to immunity to previous viral strains circulating after the 1918 pandemic until the 1950s, or during the 1957 pandemic. Thus, people born before 1957 may have had some immunity to the new virus $[12,20,22,27]$. Serosurveys, conducted in the UK and in Finland, support this hypothesis [21,28].

3. Virology. The genomes of influenza viruses are plastic. The viruses are constantly mutating and cause epidemics and pandemics $[7,25]$. The mucosal tissues of the respiratory tract are the main portal entry of influenza, and the mucosal immune system provides the first line of defence against infection. Secretory immunoglobulin A (SIgA) and IgM are the major neutralizing antibodies directed against mucosal pathogens. These antibodies work to prevent pathogen entry and can function intracellular to inhibit replication of virus [29]. Influenza A viruses are enveloped, single-stranded, negative-sense RNA viruses, belonging to the Orthomyxoviridae family of viruses [7, 23, 25]. Based on the antigenicity of the hemaglutinin (HA) and neuraminidase (NA) molecules, the influenza viruses are classified into $18 \mathrm{HA}$ (H1-H18) and $10 \mathrm{NA}$ subtypes (N1-N10) (e.g., H3N2, H1N1) [7, 23, 25]. Type A viruses undergo antigenic shift (rapid changes) and antigenic drift (gradual changes). Therefore, the type A viruses are associated with pandemics [10]. The current novel A/H1N1 or the S-OIV H1N1 pandemic viruses resulted from the reassortment of human, swine, and avian viruses [7, 10, 21, 25]. Thus, the term "swine flu" is a mongrel, a misnomer $[10,21]$.

4. Vaccines. The rapid spread of the novel pandemic flu with a high rate of mortality and morbidity highlighted the need for outbreak control, surveillance and novel vaccine development. Nowadays, monovalent, trivalent, and quadrivalent vaccines are used. The following formulas are available: inactivated/killed viruses (whole, split or virus subunits), and live attenuated/weakened (LAIV) viruses, given by injection, nasal spray, and intradermal route. Live attenuated vaccines stimulate the immune system, elicit both humoral and cellular immune responses, and are considered superior to inactivated vaccines. In addition, LAIV vaccines provide better protection than inactivated vaccines in infants and young children $[7,10,15,25,30]$.

5. Adjuvants. Adjuvants enhance the immunogenicity of vaccines and improve immune responses to flu vaccines. In Europe and in Canada vaccines with adjuvants (for instance, adjuvants $\mathrm{ASO} 3, \mathrm{AlOH}_{3}$ and MF-59) are used, and in the US - the vaccines mostly do not contain adjuvants $[9,30,31]$. New vaccines (such as DNA vaccines), viruslike particles, vectored vaccines, and new adjuvants lead to innovative vaccines with better protection [7].

Despite advantages of the adjuvants, there is a possibility of adverse events caused by some ingredients of newly developed vaccines. Monitoring of the novel pandemic flu vaccination programmes has not been totally comprehensive, and pandemic flu vaccines with novel adjuvants and other ingredients might not have been sufficiently tested before being authorised in fast-track procedures [22, 32, 33]. Thus, no sufficient information was available about the benefits and risks of the new vaccines. The pandemic 2009 H1N1 vaccines were evaluated in limited clinical trials and no extensive pre-clinical testing in animals was performed [31,32].

For pandemic flu control, the main vaccine used for vaccination in Europe was Pandemrix: Pandemrix INN adjuvanted H1N1 Pandemic influenza vaccine (split virion, inactivated). In Canada - a similar vaccine Arepanrix was used. Pandemrix was given in 2009/2010 to at least 30.8 million Europeans in 19 EU/EEA countries [34]. The use of adjuvanted vaccine Pandemrix showed association with increased incidence of narcolepsy in children after vaccination in some of European countries: Finland, Sweden, Iceland, Norway, Ireland, France [1-6, 34, 35-37]. As of early May 2011, 263 reports suggestive of narcolepsy and mentioning Pandemrix have been recorded in the EU Eu- 
draVigilance database [36].

6. Adverse events after flu vaccination. Although the vaccination is the most effective and cost-effective way to prevent infections, no vaccine is safe. Immunization can cause side effects [13, 28, 38]. When vaccine side effects are reported, the following criteria are used to assess a causal relationship: strength of the association, consistency, specificity, temporal association, dose-response effect, biological plausibility, coherence, experimental evidence, and analogy to other biologic systems [13].

The adverse reactions after vaccination might be caused by the antigen and/or by any substances in the vaccine. Vaccine components include antigens (attenuated or killed viruses, bacterial capsular polysaccharides or proteins,

Table 1. Reported adverse events after Pandemic flu H1N1 vaccination in children

\begin{tabular}{|l|l|c|}
\hline Category & \multicolumn{1}{|c|}{ Symptoms or disease } & Ref. \\
\hline $\begin{array}{l}\text { Flu-like symp- } \\
\text { toms }\end{array}$ & fever, fatigue, myalgia, swollen glands & 6 \\
\hline $\begin{array}{l}\text { Gastrointestinal } \\
\text { symptoms }\end{array}$ & vomiting, nausea, diarrhoea & 6 \\
\hline $\begin{array}{l}\text { Injection site } \\
\text { reactions }\end{array}$ & redness, pain, swelling, skin reactions, tenderness & 6,15 \\
\hline $\begin{array}{l}\text { Allergic-type } \\
\text { reactions }\end{array}$ & $\begin{array}{l}\text { wheezing, anaphylaxis, flushing, rash, dyspnoea, urtica- } \\
\text { ria, facial oedema, hypotension, tachycardia }\end{array}$ & 6 \\
\hline $\begin{array}{l}\text { Generalized } \\
\text { common symp- } \\
\text { toms }\end{array}$ & $\begin{array}{l}\text { headaches, dizziness, fainting episodes (syncope pallor), } \\
\text { irritability, anxiety, malaise, transient limb weakness, art- } \\
\text { hralgia }\end{array}$ & 6,9 \\
\hline $\begin{array}{l}\text { Neurologic } \\
\text { symptoms }\end{array}$ & $\begin{array}{l}\text { seizures, paralysis, encephalopathy, polyradiculopathy, } \\
\text { myelopathies, peripheral nerve lesions }\end{array}$ & 3,41 \\
\hline $\begin{array}{l}\text { Autoimmune } \\
\text { disorders }\end{array}$ & $\begin{array}{l}\text { narcolepsy, cataplexy (daytime sleepiness, hypnagogic } \\
\text { hallucination, disturbed night time sleep, sleep paralysis) }\end{array}$ & $\begin{array}{c}1,2,3,4,35,36,37, \\
40,55,56,\end{array}$ \\
& Guillain Barré Syndrome (GBS), Miller-Fisher Syndrome & $30,47,54$ \\
\hline
\end{tabular}

Table 2. Narcolepsy complications in children after pandemic flu vaccination in $2009 / 2010$

\begin{tabular}{|l|c|c|c|c|c|}
\hline Country & $\begin{array}{c}\text { Total number of } \\
\text { vaccinated (who- } \\
\text { le population) }\end{array}$ & $\begin{array}{c}\text { Number of vacci- } \\
\text { nated children }\end{array}$ & $\begin{array}{c}\text { Narco- } \\
\text { lepsy cases } \\
\text { in children }\end{array}$ & $\begin{array}{c}\text { Narcolepsy } \\
\text { cases after } \\
\text { vaccination } \\
\text { in children }\end{array}$ & $\begin{array}{c}\text { Refe- } \\
\text { rences }\end{array}$ \\
\hline Finland & 2,76 million & $\begin{array}{c}915,854(4-19 \\
\text { years })\end{array}$ & 67 & $\begin{array}{c}61(4-19 \\
\text { years })\end{array}$ & 2 \\
\hline Sweden & over 6 million & & 81 & $\begin{array}{c}69(0-19 \\
\text { years })\end{array}$ & 3,55 \\
\hline Iceland & 85,318 & $\begin{array}{c}40,875(0-18 \\
\text { years })\end{array}$ & 5 & $\begin{array}{c}3(0-18 \\
\text { years })\end{array}$ & 4,34 \\
\hline Norway & 2.2 million & & & $\begin{array}{c}9(0-18 \\
\text { years })\end{array}$ & 5 \\
\hline Ireland & 1.6 million & $\begin{array}{c}852,454(0-19 \\
\text { years })\end{array}$ & 28 & $\begin{array}{c}22(0-19 \\
\text { years })\end{array}$ & 6,40 \\
\hline France & 5.7 million & $\begin{array}{c}670,000(0-15 \\
\text { years })\end{array}$ & & $\begin{array}{c}11(0-15 \\
\text { years })\end{array}$ & 36,37 \\
\hline Canada & \multicolumn{2}{|c|}{$\begin{array}{c}2 \text { million }(0-17 \\
\text { years })\end{array}$} & & $\begin{array}{c}2(0-17 \\
\text { years })\end{array}$ & 34 \\
\hline
\end{tabular}

toxoids), preservatives (thimerosal, benzethonium chloride, 2-phenoxyethanol, phenol), adjuvants, additives (ammonium sulfate, glycerin, sodium borate, polysorbate 80 , hydrochloric acid, sodium hydroxide, potassium chloride), stabilizers (fetal bovine serum, monosodium glutamate, human serum albumin, porcine gelatin), antibiotics (neomycin, streptomycin, polymyxin B), and inactivating chemicals (formalin, glutaraldehyde, polyoxyethylene) [13, 39]. Adjuvanted vaccines have a greater risk for side effects. The review of 64 clinical trials of MF-59-adjuvanted influenza vaccine showed that adverse events were more frequent in the adjuvanted group [31]. During the investigation of an increased incidence of narcolepsy in Finland, it was found that the ASO3 adjuvant containing squalene and vitamin E (administered with Pandemrix vaccine) caused the production of antibodies against the adjuvant itself [40].

The side effects after vaccination against flu in children do still occur. The adverse reactions after flu vaccines were investigated by Poser (1982), Margolis et al (1990), Hambidge at all (2006), Evans et al (2009), Tremblay et al (2010), Abdel-Haq et al (2011) and others $[9,17,30,41-43]$. After the vaccination against seasonal influenza the following side effects were reported: febrile seizures [43], wheezing [31], allergic reactions (acute anaphylaxis, erythema, local reaction, dermatitis) $[11,31,43$, 44], pain [11], flulike symptoms [31, 42], lymphadenitis, sickle cell anemia [43], giant-cell arteritis $[45,46]$, and general symptoms of malaise or headaches [11]. Many authors indicated various neurological complications, including Bell's palsy $[27,44]$, optic neuritis [17, 44], paraesthesia, myelitis, ataxia [17], and neurological complications, involving the central nervous system, encephalopathy, polyradiculopathy, myelopathies, 
peripheral nerve lesions [41], restriction of limb movement [11], multiple sclerosis [44], and Guillain-Barré syndrome (GBS) [13, 17, 31, 38]. However, most of the mentioned studies showed that frequency of such side effects were very low.

Regarding GBS, there are opposite opinions on associations between seasonal/pandemic flu vaccination and GBS [47-54]. Two studies from Korea [38, 47] and the study on data from Vaccine Adverse Events Reporting System (VAERS) [17] reported that GBS was a frequent complication after vaccination, and some authors mentioned it as a possible complication [13, 30, 31]. However, some sources concluded that associations between vaccines and GBS are only temporal; there is minimal or no increased risk of GBS [7, 30, 48, 49, 50, 51, 52]. Some authors commented and underlined that rates of GBS have been extremely low, (only 1-3 cases per million vaccinated) $[27,51,53]$, which should not discourage the population from being vaccinated.

7. Adverse events after pandemic flu vaccines. There are not many studies on pandemic flu and complications after vaccination. Most information can be obtained from reports and other formal documents. The literature search showed that adverse reations after vaccination against Pandemic influenza H1N1 in children can be divided into a few categories. In Table 1 are shown reported adverse events (symptoms or disease) within categories such as generalized common symptoms (headaches, dizziness, malaise etc.), flu-like symptoms (fever, myalgia), neurological symptoms (seizures, paralysis etc.), gastrointestinal symptoms (vomiting, diarrhoea), and allergic-type symptoms (flushing, rush etc.). Some mild site reactions were reported after injection (for instance, pain, redness, and swelling). Special attention in the literature review has been focused on the autoimmune disorders and on the most serious complication - narcolepsy with excessive daytime sleepiness and cataplexy $[1-5,35-37,40,55,56]$.

In some countries (a) the incidence of narcolepsy suddenly increased during swine flu pandemic and mass vaccination in the country when compare with previous data. For instance, in Finland, a steep 17-fold increase in the annual incidence of narcolepsy in 2010 was observed (in children under 17 years) as compared to previous years. In addition, in 2009/2010, in Finland after the use of ASO3 adjuvanted A H1N1 monovalent vaccine Pandemrix, an increase was observed in the incidence of narcolepsy with cataplexy in children aged 4-19 years [1, 2]. In Iceland, increased narcolepsy diagnoses in the age group $0-18$ years for 2010 were reported (and of the five cases diagnosed, three were vaccinated with Pandemrix) [4, 34]. In France, in children under 16 years during vaccination period (with
Pandemrix and Panenza) the cases of narcolepsy exceeded the numbers expected $[36,37]$.

In addition, (b) the incidence of narcolepsy was much higher in vaccinated group when compare with unvaccinated ones. In Finland, the incidence of narcolepsy in 4-19 year old children was 12.7 -fold higher as compared to unvaccinated ones (9.0 in the vaccinated group as compared to $0.7 / 100,000$ person years in the unvaccinated individuals) [2]. Similar results were found in Sweden, where a 7-fold incidence of narcolepsy with cataplexy was reported in children vaccinated with Pandemrix compared to unvaccinated children (the incidence in vaccinated children was 4.2 per 100,000 compared with $0.64 / 100,000$ personyears in unvaccinated ones) $[3,55]$. In Ireland, the incidence of narcolepsy in children aged 5-19 years was 13-fold higher compared with unvaccinated ones (5.8 in the vaccinated and 0.5 in the unvaccinated children per 100,000 person years) [6].

Despite of said, studies revealed that the numbers of complications like narcolepsy in children are extremely low, compared with the numbers of vaccinated against pandemic flu.

Table 2 shows that various studies from the countries, where narcolepsy complications after pandemic flu vaccination occurred, reported relatively little numbers of narcolepsy cases when compare with the numbers of vaccinated. It shows that level of complications after vaccination is relatively low. Of the millions of vaccinated people, only relatively few numbers of narcolepsy cases appeared in children. Various studies showed that risk ration was very low, when compare the numbers of vaccinated children and the cases of narcolepsy after vaccination. There come some examples. In Finland, vaccine-attributable risk of developing narcolepsy was only 1: 16,000 (in age group 4-19 years) [2]. In Sweden, the added risk associated with vaccination was only about 3 cases of narcolepsy per 100, 000 vaccinated children aged 0 - 19 years [34]. In Norway, the excess risk of narcolepsy after vaccination was only 3/100,000 children aged 0-18 years [5]. In Ireland, absolute increased risk associated with the vaccine was only five narcolepsy cases per 100, 000 vaccinated children aged 5-19 years [6]. In France, 4.1 million people were vaccinated with adjuvanted Pandemrix (25 cases of narcolepsy, 20 of them with cataplexy), and 1.6 million - with unadjuvanted Panenza (2 cases of narcolepsy) (totally 5.7 million vaccinated). Only 11 cases of narcolepsy in children aged 0-15 years were reported after Pandemrix, and 2 after Panenza vaccines [36, 37]. In Canada, from 2 million vaccinated children aged 0-17 years only two cases of narcolepsy after 
ASO3-adjuvanted H1N1 Pandemic Flu Vaccine Arepanrix admission were recorded [34].

The narcolepsy cases were reported mainly in children. Thus, as a response, the European Commission recommended that the vaccine should not be given to individuals under 20 years of age [57]. In 2011, the European Commission's DG SANCO stated that only a few EU countries were still using Pandemrix, but not for children under age of 20, and the numbers are diminishing [34].

Vaccination is still an important way of prevention. For instance, in Finland during the first flu wave in 2009-2010, vaccination prevented approximately an estimated 40,000 cases of pandemic (swine) flu, and during the second wave in 2010-2011, another 40,000 cases of pandemic flu were prevented [35]. It is evident that the magnitude of the vaccination benefit is much higher than the harm of the vaccination side effects.

\section{Conclusion}

The Pandemic flu virus A $\backslash$ H1N1 S-OIV has resulted in epidemics, affecting mainly children and young people. Despite adverse events were recorded after vaccination against pandemic flu, side effects bear very small proportion of all vaccinated. Vaccination against Pandemic flu can cause generalized, flu-like, neurological, gastrointestinal, and allergic-type symptoms. A more serious complication, which has been identified, is narcolepsy with cataplexy. The incidence of narcolepsy with cataplexy in children and adolescents in European countries increased during the pandemic and vaccination period. The use of adjuvants has been shown to provoke some adverse events; in most countries, where narcolepsy in children has been reported, an adjuvanted vaccine was used.

Despite the above, vaccination remains the most effective way to protect populations from pandemic flu and other communicable diseases. However, concerns about the risks of adverse events should not be overlooked. Vaccination safety remains a priority issue in vaccination science. It is of high importance to devout finances, to form vaccine policy, to coordinate vaccine research, and to promote vaccine investigation, creation, and improvements. Safe vaccination will encourage population and empower societies for wider usage of vaccination as the mean for flu control, especially in children.

\section{Conflicts of interest}

Authors has no conflicts of interest to declare. This study was not supported financially and there is no non-financial competing interest.

\section{Acknowledgments}

Sincere thanks to Prof. Dr. Seppo Meri (Finland) for his valuable critiques, advice, and help, and to Mr. Richard Hammersley (UK) for his assistance with the English language.

\section{References}

1. Partinen M, Saarenpää-Heikkilä O, Ilveskoski I, Hublin C, Linna M. et al. Increased incidence and clinical picture of childhood narcolepsy following the $2009 \mathrm{H} 1 \mathrm{~N} 1$ pandemic vaccination campaign in Finland. PLoS ONE. 2012; 7(3):e33723.

http://dx.doi.org/10.1371/journal.pone.0033723

2. Nohynek H, Jokinen J, Partinen M, Vaarala O, Kirjavainen T. et al. AS03 Adjuvanted AH1N1 vaccine associated with an abrupt increase in the incidence of childhood narcolepsy in Finland. PLoS ONE. 2012; 7(3):e33536.

http://dx.doi.org/10.1371/journal.pone.0033536

3. Occurrence of narcolepsy with cataplexy among children and adolescents in relation to the H1N1 pandemic and Pandemrix vaccinations: Results of a case inventory study by the MPA in Sweden during 2009-2010. The Swedish Medical Products Agency (Lakemedelsverket), 2011.08.12.

4. Does vaccination against swine influenza (H1N1) cause narcolepsy? Icelandic Medicines Agency, 14 Jan 2011. Available: http://www.landlaeknir.is/Pages/1441?NewsID=2213. Accessed 2014 December 10.

5. Pandemrix og narkolepsi - flere studier nødvendig. Statens legemiddelverk (Norwegian Medicines Agency). Available: http://www.slv.no/templates/InterPage__ 82895. aspx?filterBy=CopyToGeneral. Accessed 2014 September 12.

6. Suspected adverse reactions to pandemic (H1N1) 2009 vaccines occurring in Ireland. Update on national monitoring experience with pandemic H1N1 vaccines. Irish Medicines Board. Dublin, 14th Jan 2010. Available: http://www.imb.ie/images/uploaded/ documents/imb_h1n1_vaccines_update_14jan10.pdf.Accessed 2014 June 2.

7. Tosh PK, Jacobson RM, Poland GA. Influenza vaccines: From surveillance through production to protection. Mayo Clin Proc. 2010; 85(3):257-73.

http://dx.doi.org/10.4065/mcp.2009.0615

8. Cox CM, Blanton L, Dhara R, Brammer L, Finelli L. CID. 2011;52(1):S69-S74.

http://dx.doi.org/10.1093/cid/ciq011

9. Abdel-Haq NM, Asmar BI. Novel swine-origin Influenza A: The 2009 H1N1 influenza virus. Indian J Pediatr. 2011;78:74-80. http://dx.doi.org/10.1007/s12098-010-0251-6

10. Gordon SM. Update on 2009 pandemic influenza A (H1N1) virus. Cleve Clin J Med 2009;76 (10):577-82. http://dx.doi.org/10.3949/ccjm.76a.05009

11. Ruben FL. Inactivated influenza virus vaccines in children. 
CID. 2004;38 (5):678-88.

http://dx.doi.org/10.1086/382883

12. Gilmour H, Hofmann N. H1N1 vaccination. Health Rep 2010; 21(4): 63-9.

13. Piyasirisilp S, Hemachudha T. Neurological adverse events associated with vaccination. Curr Opin Neurol 2002; 15: 333-8. http://dx.doi.org/10.1097/00019052-200206000-00018

14. Eastwood K, Durrheim DN, Jones A, Butler M. Acceptance of pandemic (H1N1) 2009 influenza vaccination by the Australian public. MJA. 2010;192(1):33-6.

15. Seale H, Heywood AE, McLaws ML, Ward KF, Lowbridge CP. et al. Why do I need it? I am not at risk! Public perceptions towards the pandemic (H1N1) 2009 vaccine. BMC Infect Dis 2010;10: 99.

http://dx.doi.org/10.1186/1471-2334-10-99

16. Schwarzinger M, Flicoteaux R, Cortarenoda S, Obadia Y, Moatti JP. Low acceptability of A/H1N1 pandemic vaccination in French adult population: Did public health policy fuel public dissonance? PLoS One 2010; 5 (4): e10199.

http://dx.doi.org/10.1371/journal.pone.0010199

17. Evans D, Cauchemez S, Hayden FG. "Prepandemic" immunization for novel influenza viruses, "Swine flu" vaccine, Guillain-Barré Syndrome, and the detection of rare severe adverse events. J Infect Dis 2009; 200(3): 321-8.

http://dx.doi.org/10.1086/603560

18. Garcia-Garcia L, Valdespino-Gómez JL, Lazcano-Ponce E, Jimenez-Corona A, Higuera-Iglesias A, et al. Partial protection of seasonal trivalent inactivated vaccine against novel pandemic influenza A/H1N1 2009: case-control study in Mexico City. BMJ. 2009;339:b3928.

http://dx.doi.org/10.1136/bmj.b3928

19. Chang LY, Shih SR, Shao PL, Huang DTN, Huang LM. Novel Swine-origin Influenza Virus A (H1N1): The first pandemic of the 21st century. J Formos Med Assoc. 2009;108 (7): 526-32. http://dx.doi.org/10.1016/S0929-6646(09)60369-7

20. Chowell G, Bertozzi SM, Arantxa Colchero M, Lopez-Gatell H, Alpuche-Aranda C, et al. Severe respiratory disease concurrent with the circulation of H1N1 influenza. N Engl J Med 2009; 361:674-9.

http://dx.doi.org/10.1056/NEJMoa0904023

21. Deshpande JD, Phalke DB, Phalke VD. Swine Flu": the return of pandemic. Pravara Med Rev 2009;4(3):4-7.

22. Fisher BL. Swine flu vaccine: Will we have a choice? US National Vaccine Information Center, 2009. Available at: http:// www.nvic.org/NVIC-VaccineNews/June-2009/Swine-FluVaccine-Will We Have A Choice-byBarba.aspx, accessed 15 June, 2011.

23. Peiris JS, Poon LL, Guan Y. Emergence of a novel swine-origin influenza A virus (S-OIV) H1N1 in humans. J Clin Virol 2009;45:169-73.

http://dx.doi.org/10.1016/j.jcv.2009.06.006
24. Devaux I, Kreidl P, Penttinen P, Salminen M, Zucs P, et al. Initial surveillance of 2009 influenza A (H1N1) pandemic in the European Union and European economic area, April September 2009. Euro Surveill 2010; 15 (49): 6-17.

25. Neumann G, Noda T, Kawaoka Y. Emergence and pandemic potential of swine-origin H1N1 influenza virus. Nature 2009; 459(7249): 931-9.

http://dx.doi.org/10.1038/nature08157

26. Patel R, Longini IM Jr, Halloran ME. Finding optimal vaccination strategies for pandemic influenza using genetic algorithms. J Theor Biol 2005; 234 (2): 201-12.

http://dx.doi.org/10.1016/j.jtbi.2004.11.032

27. Tishler M, Shoenfeld Y. Vaccination may be associated with autoimmune diseases. IMAJ. 2004;6:430-2.

28. Chen RT, Rastogi SC, Mullen JR, Hayes SW, Cochi SL, et al. The vaccine adverse event reporting system (VAERS). Vaccine 1994;12 (6): 542-50. http://dx.doi.org/10.1016/0264-410X(94)90315-8

29. Cox RJ, Brokstad KA, Ogra P. Influenza virus: Immunity and vaccination strategies. Comparison of the immune response to inactivated and live, attenuated influenza vaccines. Scand J Immunol 2004;59(1):1-15.

http://dx.doi.org/10.1111/j.0300-9475.2004.01382.x

30. Tremblay ME, Closon A, D'Anjou G, Bussières JF. GuillainBarré Syndrome following H1N1 immunization in a paediatric patient. Ann Pharmacother 2010; 44 (7):1330-3.

http://dx.doi.org/10.1345/aph.1P078

31. Libster R, Edwards KM. Influenza and influenza vaccination in children. In: Rappuoli R, Del Giudice G, editors. Influenza vaccines for future. 2 nd edition. Berlin: Springer Basel AG; 2011; 149-172.

http://dx.doi.org/10.1007/978-3-0346-0279-2_7

32. Cohen D, Carter P. WHO and the pandemic flu "conspiracies". BMJ. 2010; 340:c2912.

http://dx.doi.org/10.1136/bmj.c2912

33. Wijnans L, de Bie S, Dieleman J, Bonhoeffer J, Sturkenboom M. Safety of pandemic H1N1 vaccines in children and adolescents. Vaccine 2001; 29(43): 7559-71.

http://dx.doi.org/10.1016/j.vaccine.2011.08.016

34. Reports of cases of narcolepsy and cataplexy in children and adolescents in Finland, Iceland, and Sweden. European Centre for disease prevention and control. Stockholm, 02 March 2011. Available:

35. Association between Pandemrix and narcolepsy confirmed among Finnish children and adolescents. National Institute for Health and Welfare (THL), Helsinki, Finland, 2011 Sep 1. Available: $\mathrm{http}: / /$ www.thl.fi/en_US/web/en/pressrelease?id=26352. Accessed 2014 November 10.

36. Narcolepsy following pandemic influenza A H1N1 2009 vaccination - ECDC update: the European Medicines Agency interim measures for Pandemrix. European Centre for Disease 
Prevention and Control. Stockholm, 27 May 2011. Available: http://www.ecdc.europa.eu/en/activities/sciadvice/Lists/ ECDC\%20Reviews/ECDC_DispForm.aspx?List=512ff74f\% 2D77d4\%2D4ad8\%2Db6d6\%2Dbf0f23083f30\&ID=1088\& RootFolder $=\% 2$ Fen $\% 2$ Factivities $\% 2$ Fsciadvice $\% 2$ FLists $\% 2$ FECDC\%20Reviews. Accessed 2014 June 5.

37. Vaccins pandémiques grippe $\mathrm{A}(\mathrm{H} 1 \mathrm{~N} 1)$ et narcolepsie - Actualisation des données - Communiqué. Agence nationale de sécurité du médicament et des produis de santé. Available: http://www.ansm.sante.fr/S-informer/Presse-CommuniquesPoints-presse/Vaccins-pandemiques-grippe-A-H1N1-et-narcolepsie-Actualisation-des-donnees-Communique/(language)/ fre-FR. Accessed 2014 June 5.

38. Choe YJ, Cho H, Kim SN, Lee J. Serious adverse events following receipt of trivalent inactivated influenza vaccine in Korea, 2003-2010. Vaccine. 2011.

http://dx.doi.org/10.1016/j.vaccine.2011.07.129

39. Miller NZ, Goldman GS. Infant mortality rates regressed against number of vaccine doses routinely given: Is there a biochemical or synergistic toxicity? Hum Exp Toxicol 2011. http://dx.doi.org/10.1177/0960327111407644

40. Investigation of an increase in the incidence of narcolepsy in children and adolescents in 2009 and 2010. Final Report of National Narcolepsy Study Steering Committee. Dublin, 2011.Available: http://www.dohc.ie/publications/pdf/Final_Report_of_National_Narcolepsy_Study_Steering_Committee. pdf?direct=1. Accessed 2014 October 5.

41. Poser CM. Neurological complications of swine influenza vaccination. Acta Neurol Scand 1982; 66(4):413-31. http://dx.doi.org/10.1111/j.1600-0404.1982.tb06864.x

42. Margolis KL, Poland GA, Nichol KL, Macpherson DS, Meyer JD. et al. Frequency of adverse reactions after influenza vaccination. Am J Med 1990;88(1):27-30. http://dx.doi.org/10.1016/0002-9343(90)90123-U

43. Hambidge SJ, Glanz JM, France EK, McClure D, Xu S. et al. Safety of trivalent inactivated influenza vaccine in children 6 to 23 months old. JAMA. 2006;296(16):1990-7.

http://dx.doi.org/10.1001/jama.296.16.1990

44. Vellozi C, Burwen DR, Dobardzic A, Ball R, Walton K, Haber P. Safety of trivalent inactivated influenza vaccines in adults: background for pandemic influenza vaccine safety monitoring. Vaccine. 2009; 166:2217-21.

http://dx.doi.org/10.1016/j.vaccine.2009.01.125

45. Perez C, Loza E, Tinture T. Giant cell arteritis after influenza vaccination. Arch Intern Med. 2000;160:2677.

http://dx.doi.org/10.1001/archinte.160.17.2677

46. Finsterer J, Artner C, Kladosek A. et al. Cavernous sinus syndrome due to vaccination-induced giant cell arteritis. Arch Intern Med 2001;161:1008-9.

http://dx.doi.org/10.1001/archinte.161.7.1008-a

47. Choe YJ, Cho H, Bae G, Lee J. Guillain-Barré syndrome following receipt of influenza A (H1N1) 2009 monovalent vaccine in Korea with an emphasis on Brighton Collaboration case definition. Vaccine. 2011;29(11): 2066-70.

http://dx.doi.org/10.1016/j.vaccine.2011.01.007

48. Haber P, De Stefano F, Angulo FJ, Iskander J, Shadomy SV. et al. Guillain-Barré Syndrome following influenza vaccination. JAMA 2004;292(20): 2478-81.

http://dx.doi.org/10.1001/jama.292.20.2478

49. Hughes RA, Charlton J, Latinovic R, Gulliford MC. No association between immunization and Guillain-Barré Syndrome in the United Kingdom, 1992 to 2000. Arch Intern Med 2006;166:1301-4.

http://dx.doi.org/10.1001/archinte.166.12.1301

50. Haber P, Sejvar J, Mikaeloff Y, DeStefano F. Vaccines and Guillain-Barré syndrome. Drug Saf 2009;32(4): 309-23. http://dx.doi.org/10.2165/00002018-200932040-00005

51. Lehmann HC, Hartung H, Kieseier BC, Hughes RAC. GuillainBarré syndrome after exposure to influenza virus. Lancet Infect Dis 2010; 10 (9): 643-51. http://dx.doi.org/10.1016/S1473-3099(10)70140-7

52. Lasky T, Terracciano GJ, Magder L, et al. The Guillain-Barré syndrome and the 1992-1993 and 1993-1994 influenza vaccines. N Engl J Med 1998; 339:1797-1802.

http://dx.doi.org/10.1056/NEJM199812173392501

53. Slade BA, Gee J, Broder KR, Vellozzi C. Letter to the Editor. Comment on the contribution by Souayah et al., "GuillainBarré syndrome after Gardasil vaccination: Data from Vaccine Adverse Event Reporting System 2006-2009". Vaccine. 2011; 29: 865-6.

http://dx.doi.org/10.1016/j.vaccine.2010.11.031

54. Dieleman J., Romio S., Johansen K., Weibel D., Bonhoeffer J., Sturkenboom M. Guillain-Barre syndrome and adjuvanted pandemic influenza A (H1N1) 2009 vaccine: multinational case-control study in Europe. BMJ. 2011; Jul 12;343:d3908. http://dx.doi.org/10.1136/bmj.d3908

55. Report from an epidemiological study in Sweden on vaccination with Pandemrix narcolepsy. The Swedish Medical Products Agency (Lakemedelsverket), 2011. Available at: http://www. lakemedelsverket.se/english/All-news/NYHETER-2011/ Report-from-an-epidemiological-study-in-Sweden-on-vaccination-with-Pandemrix-and-narcolepsy-/, accessed November $1,2014$.

56. National Narcolepsy Task Force Interim Report on the association of narcolepsy and pandemic vaccine. National Institute for Health and Welfare (THL). Helsinki, 31 January 2011. Available: http://www.thl.fi/thl-client/pdfs/f890b9f3-99224efe-889b-157fe2e03aa4. Accessed 2014 November 2.

57. Recommendation by the European Medicines Agency concerning Pandemrix vaccination and reports of narcolepsy in children and adolescents. European Centre for Disease Prevention and Control. Stockholm, 21 Jul 2011. 


\section{NEPAGEIDAUJAMI REIŠKINIAI PO VAIKŲ SKIEPIJIMO NUO PANDEMINIO GRIPO A/H1N1: DĖMESYS VAKCINACIJOS SAUGUMUI B. Strukčinskienè, S. Griškonis}

Raktažodžiai: nepageidaujami reiškiniai, vaikai, pandeminis gripas, skiepijimas, saugi vakcinacija.

Santrauka

Vakcinacija arba skiepijimas yra pagrindinè priemonė infekcines ligas kontroliuoti ir valdyti. Skiepijimas padeda sukelti žmogui imunitetą infekcinėms ligoms. Vis dèlto skiepai kartais gali turèti šalutini poveikị, sukelti nepageidaujamus, šalutinius reiškinius ir nepageidaujamas reakcijas. Po to, kai pasaulyje 2009 metais išplito naujas pandeminis (vadinamasis "kiaulių") gripas A/H1N1 ir buvo inicijuota masinè vakcinacija, kai kuriose šalyse ženkliai išaugo vaikų narkolepsijos su katapleksija atvejų skaičius. Tai sulaukè medicinos ir visuomenès sveikatos specialistų bei visuomenès dėmesio. Minètos komplikacijos padidino susidomèjimą registruotais pašaliniais reiškiniais, šalutiniu poveikiu, nepageidaujamomis reakcijomis ir vakcinų saugumu.

Tyrimo metu atlikta integruota literatūros apžvalga. Kartu buvo vykdoma papildoma dokumentų ir ataskaitų paieška.

Vakcinacija gali sukelti bendro pobūdžio nepageidaujamas re- akcijas, peršalimui būdingus požymius, virškinimo organų sistemos sutrikimus, neurologinius ir alergijų tipo simptomus. Sunkesnès pasitaikančios komplikacijos yra narkolepsija su katapleksija. Tyrimas atskleidè, kad narkolepsijos su katapleksija tarp vaikų dažnis Europos šalyse padidejo pandemijos ir vakcinacijos laikotarpiu. Be to, kai kuriuos pašalinius reiškinius paskatino adjuvantų naudojimas vakcinose.

Nors po skiepijimo nuo pandeminio gripo buvo pastebėta nepageidaujamų reiškinių, šalutinis poveikis sudaro ypač mažą procentinę dalị tarp visų paskiepytujų.

Vakcinacijos saugumas išlieka prioritetine imunoprofilaktikos mokslo sritimi. Labai svarbu skirti tinkamą finansavimą vakcinacijai, formuoti imunoprofilaktikos politiką, koordinuoti mokslinius vakcinų tyrimus, skatinti vakcinų saugumo tyrimus, vakcinų kūrimą ir tobulinimą. Saugi vakcinacija paskatins žmones skiepytis ir igalins visuomenę taikyti vakcinaciją kaip gripo valdymo ir kontrolès priemonę, ypač vaikų grupèje.

Adresas susirašinèti: birutedoctor@hotmail.com

Gauta 2016-10-13 